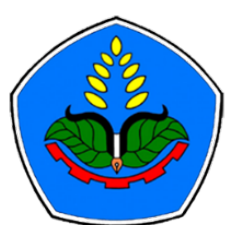

AGROPROSS

National Conference

Proceedings of Agriculture

\section{Proceedings:}

Peningkatan Produktivitas Pertanian Era Society 5.0 Pasca Pandemi

Tempat : Politeknik Negeri Jember

Tanggal : 22 Juli 2021

Publisher :

Agropross, National Conference Proceedings of Agriculture

ISBN : 978-623-94036-6-9

DOI : 10.25047 /agropross.2021.219

\title{
Analisis Regresi Karakter Kuantitatif Tongkol Terhadap Produksi Benih Jagung Manis (Zea Mays Saccharata Sturt)
}

\author{
Author(s): Nur Laila Sari ${ }^{(1)^{*}}$, Sri Rahayu ${ }^{(1)}$ \\ (1) Teknik Produksi Benih, Produksi Pertanian, Politeknik Negeri Jember \\ * Corresponding author: nurlailasari89@gmail.com
}

\begin{abstract}
The effort for increasing sweet corn seed production is held to fulfill National seed demand independently. The biggest output expected from sweet corn cultivation is the seed that has close relationship with the characters of cob. The environmental condition and the right cultivation techniques make plants fully express phenotypic character. This research aims to determine the relationship between quantitative characters of cob toward seed production using linear regression test. The research conducted on October 2020 until February 2021 in Research and Development land of PT. Wira Agro Nusantara Sejahtera Kediri. The data will be analyzed using linear regression test on the Microsoft excel. The result showed that the character of weight of cob and the number of seed per cob toward the weight of seed per cob have regression value 0,5. Meanwhile, the character of cob diameter has regression value 0,8 toward the weight of seed per cob and cob length has regression value 0,8 toward the number of seed per cob that has positive correlation with seed production.
\end{abstract}

Keywords:

Seed production;

sweet corn;

quantitative characters of $c o b$

\section{Kata Kunci: ABSTRAK}

Jagung manis;

Karakter kuantitatif tongkol;

produksi benih efek;
Upaya peningkatan produksi benih jagung manis dilakukan dengan berbagai cara untuk memenuhi kebutuhan benih nasional secara mandiri. Output terbesar yang diharapkan dari budidaya jagung manis adalah benih yang memiliki hubungan erat dengan karakter tongkol tanaman. Kondisi lingkungan dan teknik budidaya yang tepat dapat membuat tanaman mengekspresikan karakter fenotip secara maksimal. Penelitian ini bertujuan untuk mengetahui hubungan karakter kuantitatif tongkol jagung manis terhadpa produksi benih melalui uji regresi secara linier. Penelitian ini dilakukan pada bulan Oktober 2020 sampai Februari 2021 di lahan Research and Development PT. Wira Agro Nusantara Sejahtera Kediri. Data yang diperoleh dianalisa menggunakan analisis regresi secara linier pada Microsoft excel. Berdasarkan data yang diperoleh dapat diketahui bahwa karakter berat tongkol dan jumlah biji per tongkol terhadap berat benih per tongkol memiliki nilai regresi sebesar 0,5. Sedangkan karakter diameter tongkol memiliki nilai regresi sebesar 0,8 terhadap berat benih per tongkol dan panjang tongkol memiliki nilai regresi sebesar 0,8 terhadap jumlah benih per tongkol yang berkorelasi positif dengan produksi benih. 


\section{PENDAHULUAN}

Jagung manis (Zea mays saccharata Sturt) merupakan salah satu tanaman serealia yang cukup populer di kalangan masyarakat di Indonesia dengan ciri khas rasa yang manis, karena memiliki kandungan zat gula lebih tinggi dari pada jagung komposit. Menurut Lamdo dkk, (2019) keberadaan jagung manis dengan kandungan glukosa dan rendah lemak mampu menduduki posisi sebagai salah satu tanaman penting setelah padi. Jagung manis memiliki kandungan gizi yang baik untuk dikonsumsi dan menjadi pilihan yang tepat untuk menurunkan berat badan. Budidaya jagung manis telah diusahakan oleh mayoritas petani disetiap daerah, sehingga pemerataan jagung manis sebagai sayur telah dijangkau oleh hampir seluruh penduduk Indonesia. Semakin banyak petani yang membudidayakan jagung manis, maka semakin besar peluang tercukupinya kebutuhan jagung manis nasional (Kartika, 2019).

Pada tahun 2017 produksi jagung manis nasional mencapai $28,924,015$ ton dan mengalami peningkatan pada tahun 2018 sebesar 30,055,623 ton. Salah satu wilayah dengan produksi jagung manis yang cukup tinggi di Indonesia adalah Provinsi Jawa Timur dengan total produksi jagung manis pada tahun 2017 sebesar 6,335,252 ton (BPS, 2018). Akan tetapi, produksi tersebut masih belum mencukupi kebutuhan sayur jagung manis masyarakat apabila sampai saat ini jumlah penduduk di Jawa Timur mencapai 39,292,972 jiwa (BPS, 2019). Upaya peningkatan kebutuhan sayur jagung manis akan berkaitan dengan peningkatan jumlah benih tersedia dengan mutu sesuai standart yang telah ditetapkan. Sehingga peningkatan produksi dan mutu benih jagung manis perlu dilakukan untuk menjaga kestabilan produksi serta mengurangi impor benih sebagai upaya pemenuhan kebutuhan jagung manis Nasional secara mandiri.
Upaya peningkatan hasil jagung manis juga berkaitan erat dengan karakter kuantitaif fenotip tanaman yang dapat menunjukkan kuantitas produksi tanaman melalui hasil fenotip yang ditampilkan (Firdaos, dkk, 2018). Output terbesar yang diharapkan dari budidaya tanaman jagung manis adalah berat benih yang berkorelasi dengan karakter tongkol. Masing-masing varietas tanaman jagung manis memiliki penciri khusus pada tongkolnya, mulai dari jumlah tongkol dalam satu tanaman, diameter tongkol, berat tongkol, panjang tongkol hingga jumlah biji yang mengisi tongkol. Oleh karena itu, diperlukan analisis regresi pada karakter kuantitatif tongkol terhadap produksi benih jagung manis. Analisis regresi merupakan bentuk hubungan linier pada beberapa variabel yang hasilnya dapat digunakan sebagai prediktor dari respon variabel yang diamati. Sehingga, hasil dari analisis regresi karakter kuantitatif tongkol terhadap produksi benih yang diperoleh dapat digunakan sebagai informasi untuk petani dalam memperkirakan atau memprediksi produksi benih jagung manis yang akan dihasilkan.

\section{METODOLOGI}

Penelitian ini dilaksanakan pada bulan Oktober 2020 sampai bulan Februari 2021 bertempat di lahan Research and Development PT. Wira Agro Nusantara Sejahtera Kediri. Benih yang digunakan adalah benih induk jagung manis kelas benih dasar (Foundation Seed). Metode pengambilan jumlah sampel dilakukan secara acak sederhana (Simple Random Sampling) atas jumlah populasi yang ada sebanyak 6 tanaman dari 12 tanaman populasi tiap plot. Parameter yang diamati adalah karakter kuantitatif tongkol jagung manis yang meliputi berat tongkol tanpa kelobot, diameter tongkol tanpa kelobot, panjang tongkol tanpa kelobot, jumlah benih per tongkol dan berat benih per tongkol. Data yang diperoleh kemudian 
dikumpulkan dan dianalisis menggunakan analisis regresi linier pada Microsoft excel.

\section{HASIL DAN PEMBAHASAN}

Hasil pengamatan karakter kuantitatif akan ditunjukkan dalam bentuk data dan dari data yang diperoleh akan memunculkan grafik atau tabel yang dapat mempermudah penyampaian informasi. Berikut ini merupakan hasil rekapitulasi pengamatan karakter kuantitatif tongkol jagung manis.

Tabel 1. Rerata karakter berat tongkol, diameter tongkol, panjang tongkol, jumlah benih per tongkol dan berat benih per tongkol

\begin{tabular}{cccccc}
\hline Plot Ke- & BT & DT & PT & JB & BB \\
\hline 1 & 179,44 & 4,68 & 16,93 & 433,67 & 54,29 \\
2 & 181,67 & 4,78 & 17,95 & 453,22 & 57,19 \\
3 & 180,28 & 4,71 & 17,65 & 448,28 & 55,57 \\
4 & 185,83 & 4,68 & 17,55 & 447,48 & 54,06 \\
5 & 208,89 & 4,82 & 17,48 & 447,22 & 54,99 \\
6 & 197,22 & 4,56 & 16,79 & 439,56 & 54,64 \\
7 & 191,11 & 4,62 & 16,86 & 434,06 & 53,75 \\
8 & 192,50 & 4,84 & 17,02 & 446,94 & 54,15 \\
9 & 185,28 & 4,76 & 16,15 & 426,61 & 53,26 \\
\hline
\end{tabular}

Keterangan: BT = Berat Tongkol tanpa kelobot $(\mathrm{gr}), \mathrm{DT}=$ Diameter Tongkol tanpa kelobot $(\mathrm{cm}), \mathrm{PT}=\mathrm{Panjang}$ Tongkol tanpa kelobot $(\mathrm{cm}), \mathrm{JB}=$ Jumlah Benih per tongkol (butir), BB = Berat Benih per tongkol (gr).

\section{Berat Tongkol (gr)}

Berat tongkol diamati setelah kelobot dipisahkan dari tongkol dengan cara menimbang tongkol dari masing-masing tanaman. Berat tongkol mampu mengindikasikan hasil per tanaman yang akan diperoleh. Berikut ini merupakan analisis regresi liner berat tongkol terhadap hasil benih per tongkol. Gambar 1 di bawah ini menyajikan kurva regresi berat tongkol terhadap berat benih per tongkol.

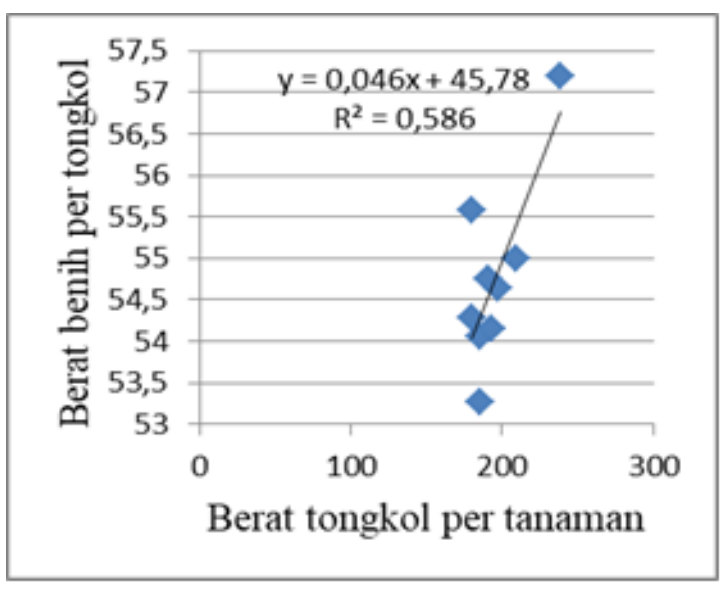

Gambar 1. Kurva Regresi Berat Tongkol terhadap Berat Benih per Tongkol
Berdasarkan Gambar 1 diperoleh nilai regresi $\left(\mathrm{R}^{2}\right)$ dari kedua variabel sebesar 0,59 , semakin besar nilai regresi atau semakin dekat nilai dengan angka 1, maka menunjukkan kedua variabel memiliki keterkaitan. Nilai regresi pada Gambar 4.1 mengartikan bahwa berat tongkol tidak berpengaruh sepenuhnya terhadap berat benih per tongkol yang dihasilkan. Berat tongkol pada plot ke-4 memiliki nilai berat tongkol tertinggi sebesar 208,89 gram yang diikuti dengan berat benih per tongkol sebesar 54,99 gram. Sedangkan pada nilai berat benih per tongkol tertinggi pada plot ke-2 sebesar 57, 19 gram. Hal tersebut dikarenakan hasil asimilat yang tersedia di dalam tanaman pada fase generatif tidak sepenuhnya ditranslokasikan menuju tongkol akan tetapi juga ditranslokasikan pada bagian daun dan bagian lain yang tidak lagi produktif (Shodikin dan Wardiyati, 2017). Kondisi tersebut menyebabkan proses perkembangan biji menjadi tidak maksimal. Selain itu, berat tongkol yang diamati adalah tongkol bruto, artinya berat tongkol diikuti dengan berat biji rusak dan 
janggel sehingga ketika benih di timbang menghasilkan nilai lebih kecil. Faktor hama dan penyakit yang menyerang tongkol jagung manis juga dapat mempengaruhi berat benih yang dihasilkan. Jumlah biji yang terbentuk dipengaruhi oleh keberhasilan proses penyerbukan, sedangkan berat biji yang diperoleh dipengaruhi penyerapan unsur hara dan penggunakan fotosintat secara maksimal. Untuk menghasilkan produksi maksimal maka diperlukan kondisi lingkungan dan teknik budidaya yang tepat sehingga segala proses metabolisme dapat berjalan secara maksimal.

\section{Diameter Tongkol (cm)}

Diameter tongkol merupakan penampang melintang dari tongkol jagung yang diukur mulai tepi tongkol hingga tepi lain dan dapat diamati menggunakan alat bantu jangka sorong. Diameter tongkol berperan penting sebagai tempat menempel dan tumbuhnya biji setelah proses penyerbukan berlangsung. Sehingga keberadaannya berkaitan secara langsung dengan jumlah benih yang dihasilkan. Di bawah ini merupakan kurva regresi diameter tongkol terhadap berat benih per tongkol.

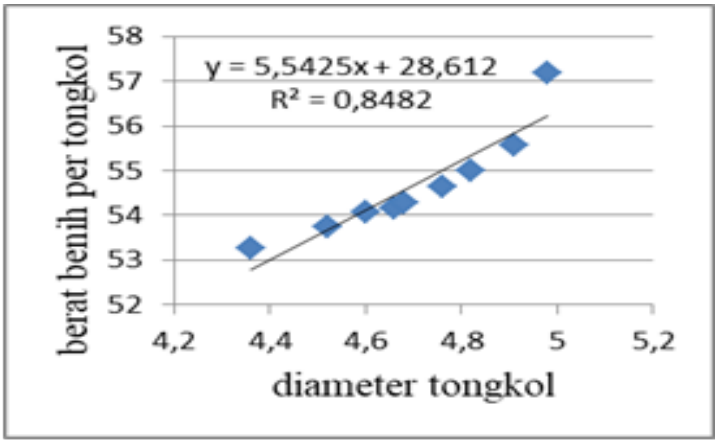

Gambar 2 Kurva Regresi Diameter Tongkol terhadap Berat Benih per Tongkol

Nilai regresi yang ditunjukkan pada Gambar 2 di atas sebesar 0,85 yang artinya peningkatan nilai diameter tongkol tanpa kelobot diikuti dengan meningkatnya nilai berat benih per tongkol. meskipun pertumbuhan diameter tongkol jagung manis cenderung berjalan lambat, dimana pemanjangan tongkol lebih dahulu direspon oleh fisiologi tanaman. Akan tetapi, ketika kebutuhan unsur hara primer pada tanaman terpenuhi dapat mendukung proses metabolisme dan asimilasi yang kemudian di transfer menuju tempat penyimpanan seperti tongkol, sehingga pembesaran tongkol jagung manis dapat terjadi secara maksimal (Resdianti dkk, 2020). Semakin besar nilai diameter tongkol maka semakin besar pula kesempatan biji untuk berkembang secara maksimal. Kebutuhan unsur hara yang terpenuhi dapat menjadi indikator keberhasilan produksi benih, menurut $\mathrm{Wu}$ and Lin (2000) penggunaan $\mathrm{N}$ berpengaruh terhadap kualitas dan kuantitas hasil terutama pada proses penyempurnaan pengisian biji secara penuh sehingga dapat mengeraskan dan mencegah pengecilan biji pada ujung tongkol.

\section{Panjang Tongkol (cm)}

Panjang tongkol merupakan salah satu parameter yang dapat diamati dan digunakan sebagai acuan untuk mengetahui produksi jagung manis. Karakter tongkol yang panjang dapat memberi keuntungan terhadap hasil benih jagung manis, karena semakin panjang tongkol maka semakin maksimal pertumbuhan biji. Sehingga, nilai karakter panjang tongkol perlu dilakukan uji regresi linier dengan jumlah benih yang dihasilkan per tongkol untuk mengetahui keeratan hubungan pada kedua variabel. Hasil regresi dapat dilihat pada Gambar 3 di bawah ini. 


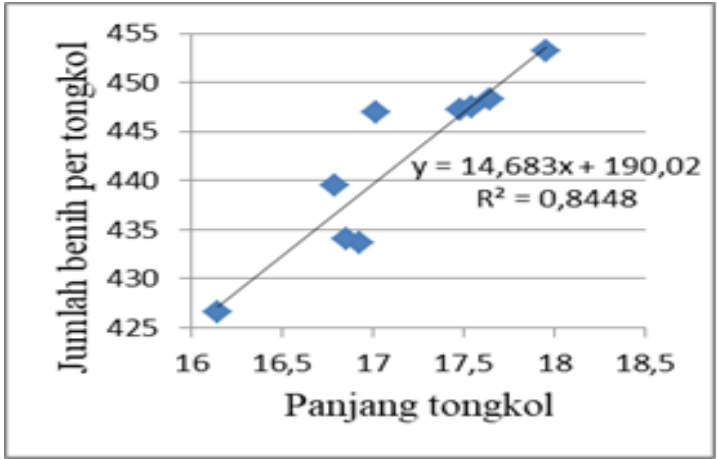

Gambar 3 Kurva Regresi Panjang

Tongkol terhadap Jumlah Benih per Tongkol

Berdasarkan kurva di atas, dapat diketahui bahwa nilai regresi yang muncul sebesar 0,85 dan mengindikasikan bahwa pemanjangan tongkol dapat berakibat pada meningkatnya jumlah benih per tongkol. semakin panjang tongkol, maka semakin banyak ruang tersedia untuk memaksimalkan pembentukan biji. Tanaman jagung manis mampu menyerap lebih banyak unsur hara pada fase generatif, karena hasil asimilat dan unsur hara yang telah terserap sebagian kecil akan digunakan untuk melangsungkan pertumbuhan dan sebagian besar digunakan untuk pembentukan biji. Pendapat yang sama juga disampaikan oleh Solihin dkk, (2019) bahwa unsur hara tersedia akan diserap tanaman pada pertumbuhan awal fase vegetatif, dan pada fase generative akan terjadi serapan hara dengan sangat cepat. Peningkatan pertumbuhan tongkol dan pembentukan biji akan diikuti dengan produksi hormon aukin yang terbentuk akibat penambahan unsur hara, kondisi tersebut mengakibatkan laju perkembangan tongkol jagung manis mengalami peningkatan. Nilai panjang tongkol yang linier dengan jumlah biji per tongkol terbentuk akan meningkat sejalan ketersediaan unsur hara dan kondisi lingkungan yang mendukung bagi tanaman untuk mengekspresikan karakter kuantitatif pada tongkol. Selanjutnya, dapat dikalkulasikan bahwa jumlah benih yang meningkat akan mempengaruhi produksi benih pada jagung manis.

\section{Jumlah Benih per Tongkol (butir)}

Biji tanaman jagung berperan penting dalam penentuan produksi, sehingga pada sistem budidaya tanaman hampir seluruh kegiatan atau perlakuan yang diberikan ditujukan untuk memaksimalkan pertumbuhan biji pada tongkol. Pengamatan jumlah biji per tongkol dilakukan dengan cara menghitung jumlah biji pada setiap tongkol per tanaman. Perhitungan dilakukan pada biji yang telah disortasi dan memenuhi syarat standart kualitas benih berdasarkan ISTA. Semakin banyak biji terbentuk dalam satu tongkol, akan mempengaruhi berat benih per tanaman yang berkorelasi dengan produksi benih jagung manis. Berikut ini merupakan hasil uji regresi linier karakter jumlah biji per tongkol terhadap berat benih per tongkol.

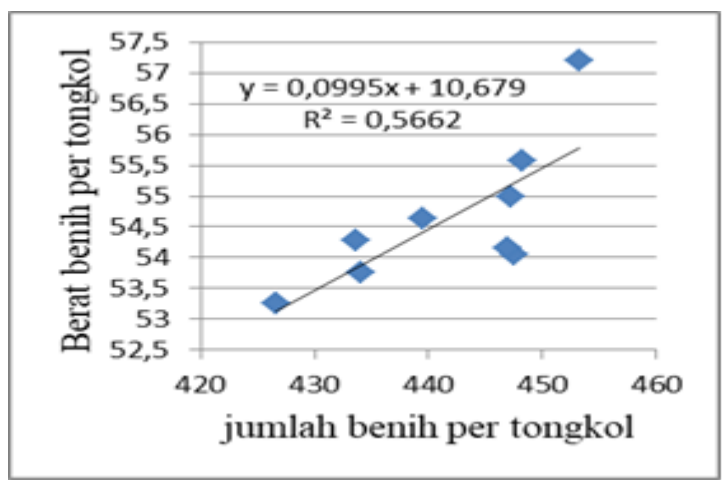

Gambar 4 Kurva Regresi Jumlah Biji per Tongkol terhadap Berat Benih per Tongkol

Kurva di atas menyajikan nilai regresi sebesar 0,57 yang artinya berdasarkan data pengamatan karakter tongkol jagung manis terutama pada jumlah benih per tongkol tidak memiliki hubungan yang sangat erat dengan berat benih per tongkol. Berat benih sangat dikaitkan dengan nilai bobot 100 butir yang 
dipengaruhi oleh volume dan ukuran benih. Benih yang memiliki nilai berat 100 butir tinggi artinya benih komponen pada benih terbentuk secara sempurna melalu nutrisi yang telah diakumulasikan secara maksimal selama proses budidaya di lapang. Berdasarkan data yang disajikan pada Tabel 1 diketahui bahwa nilai berat benih per tongkol tertinggi pada plot ke-2 sebesar 57,19 gram dengan jumlah benih terbentuk pada tongkol sebanyak 453,22 butir benih.

Berikut ini merupakan dokumentasi proses pengamatan karakter kuantitatoif tongkol jagung manis.
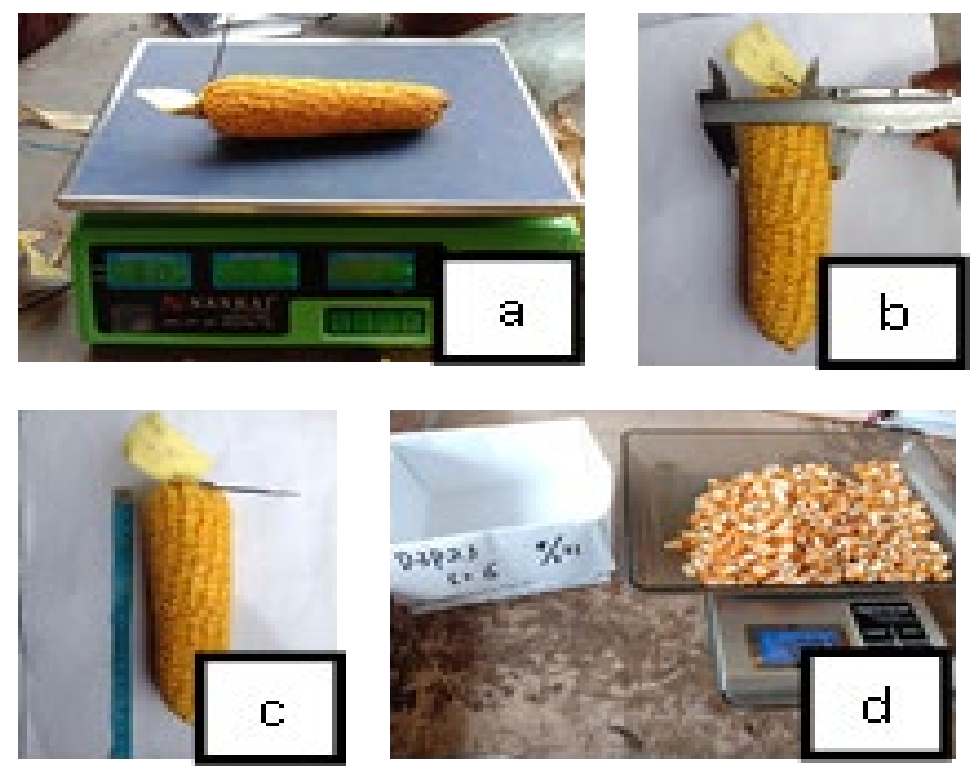

Keterangan: a) penimbangan berat per tongkol. b) diameter tongkol. c) panjang tongkol. d) berat dan jumlah benih per tongkol.

Gambar 5 Proses Pengamatan Karakter Kuantitatif Tongkol Jagung Manis

\section{KESIMPULAN}

Berdasarkan hasil uji regresi linier yang telah dilakukan pada karakter kuantitatif tongkol terhadap produksi benih jagung manis dapat diketahui bahwa tidak semua karakter tongkol jagung memiliki hubungan yang erat terhadap peningkatan hasil benih per tongkol. Kondisi lingkungan dan teknik budidaya yang tepat dapat membuat tanaman mengekspresikan karakter fenotip secara maksimal. Karakter berat tongkol dan jumlah biji per tongkol terhadap hasil benih per tongkol memiliki nilai regresi sebesar 0,5 . Sedangkan karakter diameter tongkol memiliki nilai regresi sebesar 0,8 terhadap hasil benih per tongkol dan panjang tongkol memiliki nilai regresi sebesar 0,8 terhadap jumlah benih per tongkol yang berkorelasi dengan produksi benih.

\section{DAFTAR PUSTAKA}

Badan Pusat Statistik. 2019. Jumlah Penduduk dan Rasio Jenis Kelamin Menurut Kabupaten/Kota di Provinsi Jawa Timur 2017. https://jatim.bps.go.id/statictable/20 19/10/15/1921/jumlah-pendudukdan-rasio-jenis-kelamin-menurutkabupaten-kota-di-provinsi-jawatimur-2017-.html.

Firdaos E. R., M. Jaenun, D. Saptadi dan A. N. Sugiharto. 2018. Keragaman Karakter Komponen Hasil Beberapa Populasi $\mathrm{S}_{4}$ Jagung Manis (Zea mays ssaccharata Sturt). Dalam Jurnal Produksi tanaman 6: 502-510. 
Fakultas Pertanian Universitas Brawijaya. Malang. http://protan.studentjournal.ub.ac.id /index.php/protan/article/viewFile/6 72/696

Kartika T. 2019. Potensi Hasil Jagung Manis (Zea mays saccharata Sturt.) Hibrida Varietas Bonanza F1 Pada Jarak Tanam Berbeda. Dalam Jurnal Ilmiah Matematika dan Ilmu Pengetahuan Alam 16: 55-66. Program Studi Biologi Universitas PGRI Palembang. Palembang. https://jurnal.univpgri-

palembang.ac.id/index.php/sainmati ka/article/view/2843/2677.

Lamdo H., S. Fajriani dan Sudiarso. 2019. Respon Pertumbuhan dan Hasil Jagung Manis pada Perlakuan Pupuk Tricokompos yang Dipanen pada Umur Berbeda. Dalam Jurnal Produksi Tanaman 7: 1871-1877. Universitas Negeri Malang. Malang. http://protan.studentjournal.ub.ac.id lindex.

php/protan/article/download/1249/1 266.

Resdianti, Seprido dan D. Okalia. 2020. Pengaruh Pemberian Pupuk Petroganik Terhadap Pertumbuhan Dan Produksijagung Pulut (Zea mays ceratina Kulesh). Dalam Jurnal Green Swarnadwipa 9: 63-70. Fakultas Pertanian Universitas Islam Kuantan Singingi. https://ejournal.uniks.ac.id/index.ph p/GREEN/article/view/493.

Shodikin A. dan T. Wardiyati. 2017. Pengaruh Defoliasi dan Detaseling terhadap Hasil Tanaman Jagung (Zea mays L.). Journal of Agricultural Science 2: 18-22. Fakultas Pertanian Universitas Brawijaya. Malang. https://jpt.ub.ac.id/index.php/jpt/arti cle/view/124.

Solihin E., R. Sudirja dan A. Yuniarti. 2019. Modifikasi Pupuk N Untuk Peningkatan Efisiensi Penyerapan
Hara Tanaman Jagung (Zea mays L.). Dalam Jurnal Agriwiralodra 2: 60-66. Universitas Padjadjaran Sumedang. https://agrowiralodra.unwir.ac.id/in dex.php/agrowiralodra/article/down load/19/15.

$\mathrm{Wu}$ Y. dan C. Ling. 2020. Analysis of Cytokinin Activity in Commercial Aqueous Seaweed Extract. National Chung Hsing University. Thaicung. 